\title{
Water Management Practices for Sustainable Rice Production in Nigeria.
}

\author{
Fashola O. O. ${ }^{1}$, G. O. Olaniyan ${ }^{2}$, J. Aliyu ${ }^{3}$ and T. Wakatsuki ${ }^{4}$ \\ (1) Watershed Initiative in Nigeria / Hirose Project - IITA, Ibadan, Oyo-State, E-mail: R.FASHOLA@CGIAR.ORG \\ (2) Watershed Initiative in Nigeria (WIN 2001), Bida, Niger-State, (3) Niger State Agricultural Development Project, \\ Bida, Niger-State, (4) Faculty of Agriculture, Kinki University, Nara, Japan E-mail wakatuki@nara.kindai.ac.jp
}

\section{Summary}

The importance of rice in Nigeria is no longer the question but rather how can we meet the growing demand, reduce import and be self-sufficient. Consumption per capita jumped from $2.9 \mathrm{~kg}(1970 / 74)$ to $24.1 \mathrm{~kg}(1995 / 99)$. Our production figure increased by 6 times within the period to 3.27 million tons but our importation figure by 1998 stood at 1 million tons accounting for one third of the total import for West Africa. By 1999 area harvested from rice stood at 2.2 million hectares of which $65 \%$ was from rainfed lowland. However our yield average is $1.5 \mathrm{t} / \mathrm{ha}$. There are $55 \mathrm{high}$ yielding varieties for various ecologies officially released and another 6 NERICA varieties in the pipeline for upland areas. The lowland elite varieties with good management could yield up to 6 tons per ha. But these potentials are never achieved on farmers' field because of poor water control system and bad soil management. This is why a renewed call for a concerted effort needs to be made for a better water and soil management practices referred to in this paper as *Sawah System and better policies.

\section{Introduction}

\section{Sawah hypothesis: Sawah system and Integrated Watershed Approach}

*Sawah System: The term sawah refers to levelled rice field surrounded by bund with inlet and outlet connecting irrigation and drainage canals. The term originates from Malayo-Indonesian. The English term, Paddy or Paddi, also originates from the Malayo-Indonesian term, Padi, which means rice plant. The term, Paddy, refers to rice grain with husk in Nigeria and West Africa as a whole. Most of the paddy fields in the Asian countries correspond to the definition of the term sawah. Paddy field is almost equivalent to sawah for Asian scientists. However, the term paddy fields refers to just a rice field including upland rice field in West Africa. Therefore in order to avoid confusion between the terms rice plant, paddy, and the improved man-made rice-growing environment through ecological engineering, the authors propose to use the term sawah.

Why has the green revolution not yet occurred in Nigeria and indeed West Africa in spite of its successes in Asia in the 1960s? The green revolution laid the foundation for the rapidly growing economies of Asia today. The layouts of groups of sawah in the lowlands in a watershed were adapted to the local topography for efficient irrigation and drainage. The main cause of the present agricultural and environmental crises in Nigeria and in West Africa is the general under development of lowland agriculture. Environmentally creative technology, or ecological engineering technology, such as sawah farming is not traditionally practiced in sub-Saharan Africa. Sawah is a multi-functional constructed wetland, which is the prerequisite for realizing the green revolution as well as for preserving and even restoring ecological 
environments. Irrigation and drainage without sawah farming technologies has proved inefficient or even dangerous because of accelerating erosion. Thus, the development of irrigation has been slow. In the absence of water control, fertilizers cannot be used efficiently. Consequently, the high yielding varieties perform poorly and soil fertility cannot be sustained. Hence, the green revolution cannot take place.

As shown in Fig. 1, the soils formed in uplands and the nutrients released during weathering and soil forming processes in uplands are accumulated in lowlands. If sawah system exists in the lowlands, it can store and effectively use these nutrient rich water and fertile topsoils. This is an eco-environmental basis for long-term sustainability of high productivity of Sawah based rice farming in Asia.

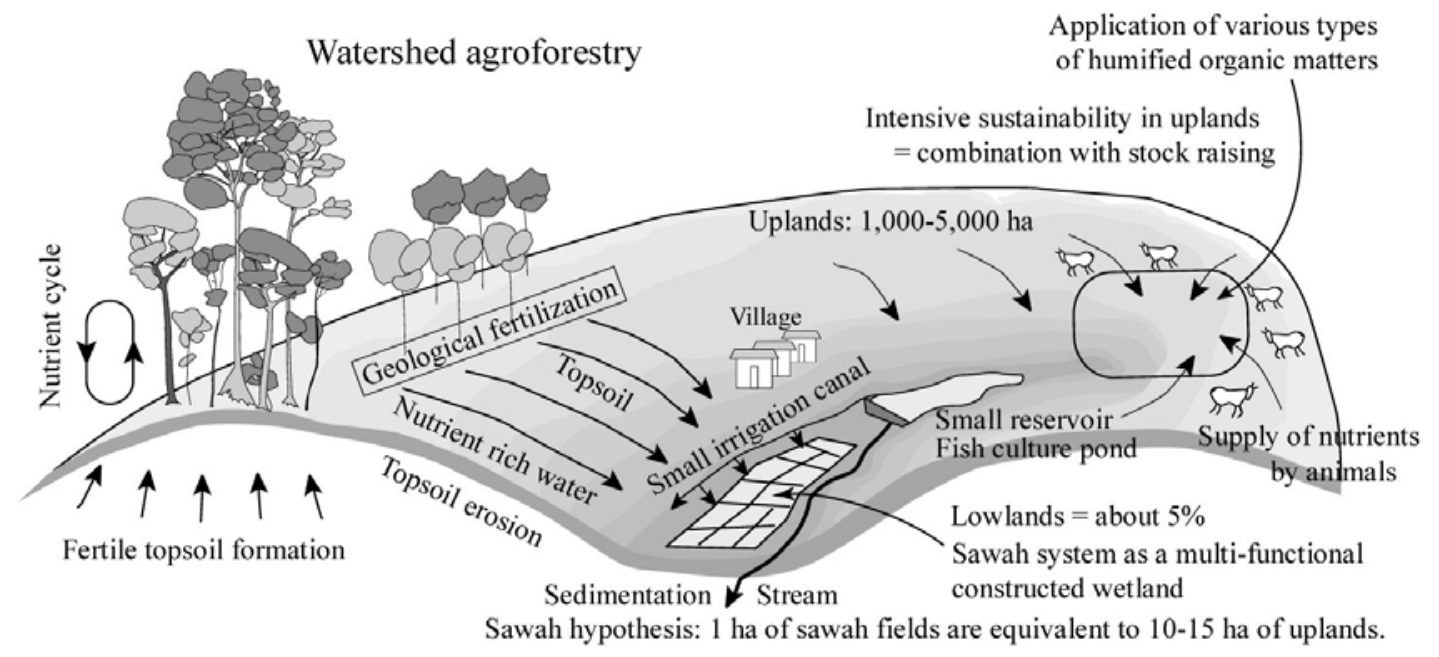

Fig 1: Watershed Agroforestry by the integration of forestry and sawah in a unit Watershed (fertile topsoil formed in forest ecosystem and sedimentation of the eroded topsoil in lowland sawah is the geological fertilization process (Wakatsuki et al 2003).

Suppose the soil formation rate in uplands, which make up $95 \%$ of the total area in the example of a watershed as shown in Fig. 1, is $1 \mathrm{t} / \mathrm{ha} / \mathrm{yr}$. In a stable ecosystem in a watershed, the rate of soil formation and erosion should be well balanced; therefore, the topsoils formed in uplands - which account for 95\% - and the nutrients produced in the process will be concentrated in the lowlands, which make up 5\% of the area. Thus the soil formation rate in the lowlands equals to $20 \mathrm{t} / \mathrm{ha} / \mathrm{yr}$. Though it will be impossible to use all of the rich soils and nutrient rich water from the uplands effectively, sawah will be the best system for making an effective use of them. A sawah system in lowlands is, as it were, the one for effectively using the interest accrued from the huge stocks named "uplands." This farming system could artificially reinforce the geological fertilization processes, which are 1) lowland soil formation and 2) regeneration of the soils. The quantitative scientific evaluation of the geological fertilization process in a watershed will be an important future research subject.

When the unit yields of upland slash and burn rice cultivation is compared to that of lowland sawah rice cultivation, the latter $(2.5 \mathrm{t} / \mathrm{ha})$ is approximately 2.5 times higher than the former $(1 \mathrm{t} / \mathrm{ha})$ under the condition of no fertilizer application. With standard fertilizer application, the unit yield of sawah rice increases to $5-6 \mathrm{t} / \mathrm{ha}$. In contrast, fertilizer application is not a viable option for rainfed upland rice cultivation because of its low efficiency unless infrastructure or land consolidation is provided to a certain degree by means of soil erosion prevention measures, etc. In addition, the planting of rice in rainfed upland areas based on the slash and burn method of farming 
must be followed by a fallow period of at least $4-5$ years to allow restoration of the soil fertility, i. e., for the sustainability of 1 ha of upland rice cultivation based on slash and burn, 4 - 5 ha of upland are necessary. In comparison, continuous cultivation is possible with sawah fields as they have various mechanisms to restore the soil fertility by geological fertilization in the watershed (Fig 1) and cultivation under submerged water condition (Fig.2). When these two types of cultivation are compared for a long period of more than 10 years, which are necessary for sustain complete cycle of slash and burn cultivation, taking the above facts into consideration, the difference in sustainable unit productivity can be more than tenfold, i.e., yield difference (2.5) times difference of required area for sustainable production (4-5). Accordingly, the development of 1 ha of sawah field enables the conservation or regeneration of 10 ha or more of forest area. Sawah fields can, therefore, contribute to not only increased food production but also conservation of the forest environment as well as soil and water conservation in the catchment area, resulting in the enhanced sustainability of an intensive lowland sawah field system. Furthermore, they can contribute to the alleviation of global warming and other global environmental problems through the fixation of carbon to forests and forest soil.

\section{Sawah system as Multi-functional constructed wetland: High sustainability}

Figures. 1 and 2 shows the various mechanisms of intensive and long terms ecological sustainability of sawah fields. It is well-known that weeds can be controlled by means of water control. But it is not well evaluated that the nitrogen fixation by soil microbes under a submerged sawah systems could reach $20-100$ $\mathrm{kg} / \mathrm{ha} /$ year in Japan and $20-200 \mathrm{~kg} / \mathrm{ha} /$ year in the tropics depending on the level of soil fertility and water management (Kyuma 2003, Hirose and Wakatsuki 2002). This amount is comparable with the nitrogen fixation amount by leguminous plants. Rainfed upland farming has no such option but rely on the use of leguminous plants, animal dung, other organic fertilizer, and or chemical fertilizers. The abovementioned advantage of the sawah field system in lowland areas through water management is not properly understood in Africa.

Under submerged condition, because of reduction of ferric iron to ferrous iron, phosphorous availability is increased and acid $\mathrm{pH}$ is neutralized, hence micronutrients availability is also increased (Kyuma 2003). There are other benefits of sawah systems. The eutrophication mechanisms are not only encouraging the growth of rice plant but also encourage the growth of various algae that increase the nitrogen fixation. The quantitative evaluation of nitrogen fixation in sawah systems including the role of algae will be also important future research topics.

Under nitrate rich submerged water conditions, sawah systems encourage denitrification. Easily decomposable organic matter become substrate of various denitrifyers. Purification of the nitrate polluted water is another function of sawah system (Kyuma 2003, Wakatsuki 2002). 


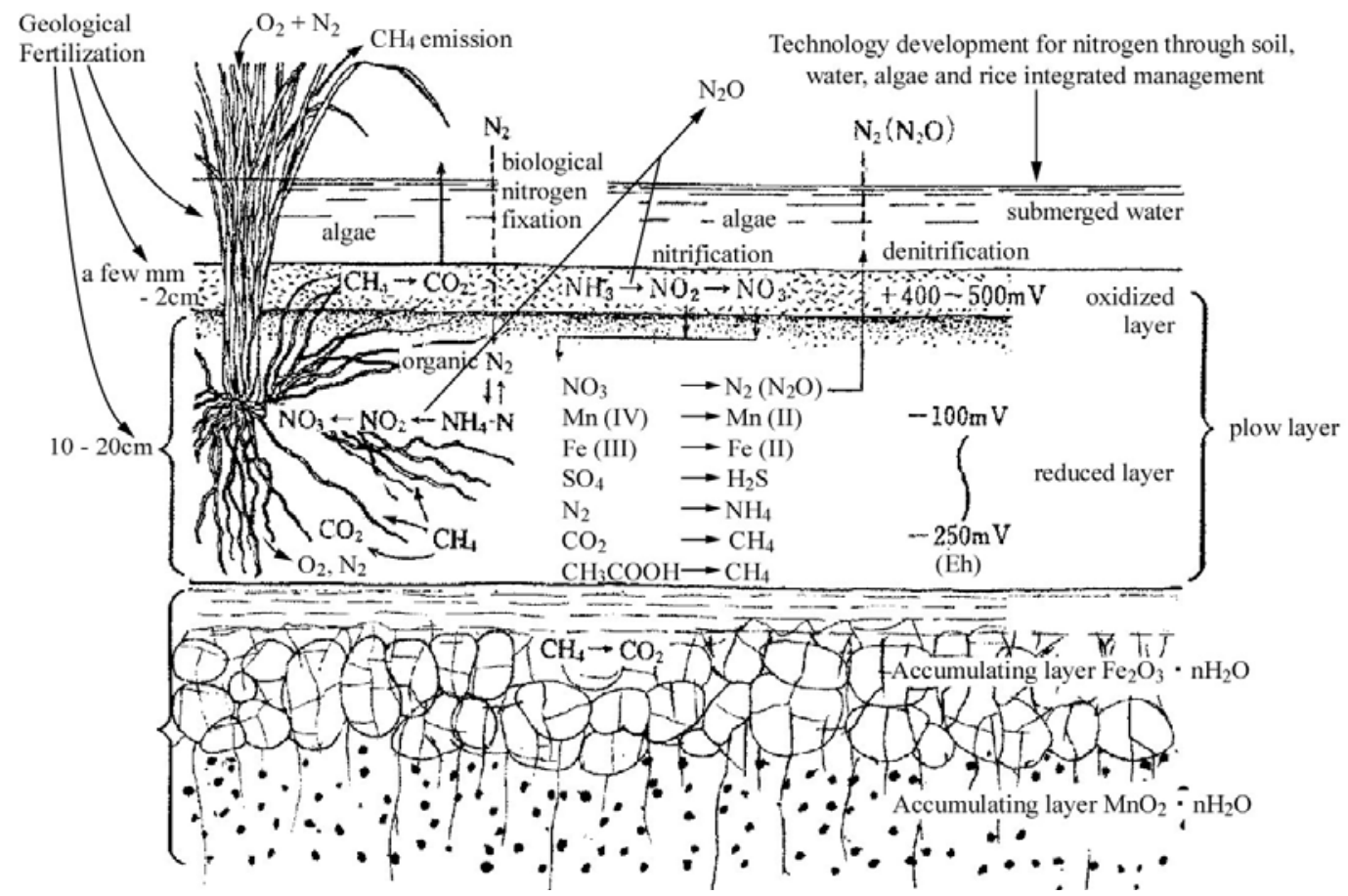

Fig 2: Morphology of sawah soil profile and various redox reactions to increase soil fertility. Sawah system - functional constructed wetlands. (Estimate nitrogen fixation is 20-200 kg N/ha/yr) (Wakatsuki et al 2003).

\section{Rice Cultivation in Nigeria}

Nigeria is the largest producer of rice in West Africa producing over $46 \%$ of the regions total production (Singh et al 1997). In the last 30 years production has increased 6 folds with Nigeria producing 3.28 million tons of paddy rice by 1999 (FAOSTAT 2004). Nigeria is equally the largest importer of rice and its importation figure stood at 1 million tons costing over $\$ 300$ million by 1998 , which is one third of the sub regions total. It has a land area potential for rice estimated to be 5 million hectares of which $65 \%$ are lowlands. In 1999 area harvested from rice was 2.2 million ha of which $65 \%$ were from lowlands. Consumption per capita jumped from $2.9 \mathrm{~kg}$ in the period between 1970-74 to $24.1 \mathrm{~kg}$ between 1995 and 1999 (Hirose and Wakatsuki 2002). Rice is undoubtedly the most important staple food for the urban dwellers and the fourth largest crop produced after sorghum, millet and maize. But its potential for growth out weighs other cereals.

The fact that rice is the only crop that can be grown in all the agro-ecological zones of Nigeria is an added advantage. Therefore Nigeria has all the growing ecologies for rice viz: 1) rainfed upland, 2) rainfed lowland, 3) irrigated lowland and 4) deep water /floating. According to WARDA (1999) the percentage of area under rice by ecology is as follows $31 \%$ for upland, $47 \%$ for lowland, $16 \%$ for irrigated and $5 \%$ for deep water (Table 1). There are 55 improved varieties released in Nigeria of which 41 varieties are for lowlands, they had been tested and proven to be responsive to fertilizer and capable of yielding up to 6 tons per ha but the average national yield per ha is still $1.5 \mathrm{t} / \mathrm{ha}$ (Singh et al 1997). Despite the increased production, the productivity per unit area had only experience a marginal increase. To put this in perspective for better understanding, yield (per square meter) in the last 30 years 
increased from $1.3 \mathrm{t} /$ ha to $1.8 \mathrm{t} / \mathrm{ha}$ whereas in tropical Asia during the same period (1970-2000) yield increase doubled from $1.8 \mathrm{t} /$ ha to 3.6 t/ha (Wakatsuki et al 2003).

This paper will be looking into why this marginal yield increase and the way forward.

Table 1: Rice Ecosystems in Nigeria with Average Yield

\begin{tabular}{|l|c|c|c|}
\hline Ecology & $\begin{array}{c}\text { Share of Rice } \\
\text { Area \% }\end{array}$ & $\begin{array}{c}\text { Average Grain } \\
\text { Yield t/ha }\end{array}$ & $\begin{array}{c}\text { Share of rice } \\
\text { production (\%) }\end{array}$ \\
\hline Rainfed upland & 31 & 1.5 & 17 \\
\hline Rainfed lowland & 47 & 2.2 & 53 \\
\hline Irrigated lowland & 16 & 3.5 & 27 \\
\hline Deepwater/floating & 5 & 1.3 & 3 \\
\hline Mangrove swamps & $\approx 1$ & 2.0 & 1 \\
\hline
\end{tabular}

\section{Looking back to past activities.}

Dr K. Nwanze WARDA Director General (1997) said "Too often, in our rush into the future to solve anticipated problems, we do not look back into the past to draw the lessons thereof. And no sooner, the tomorrows upon which our hopes were hinged become the yesteryears of the past and the lessons from today's experiences are not retained".

Past activities on rice initially centered on the upland ecology for the farmers and few irrigated lowland for large-scale production. The irrigated ecology were constructed and financed by the government, with the farmers becoming the tenants. Unfortunately this ecology was not properly administered and with inconsistent policy

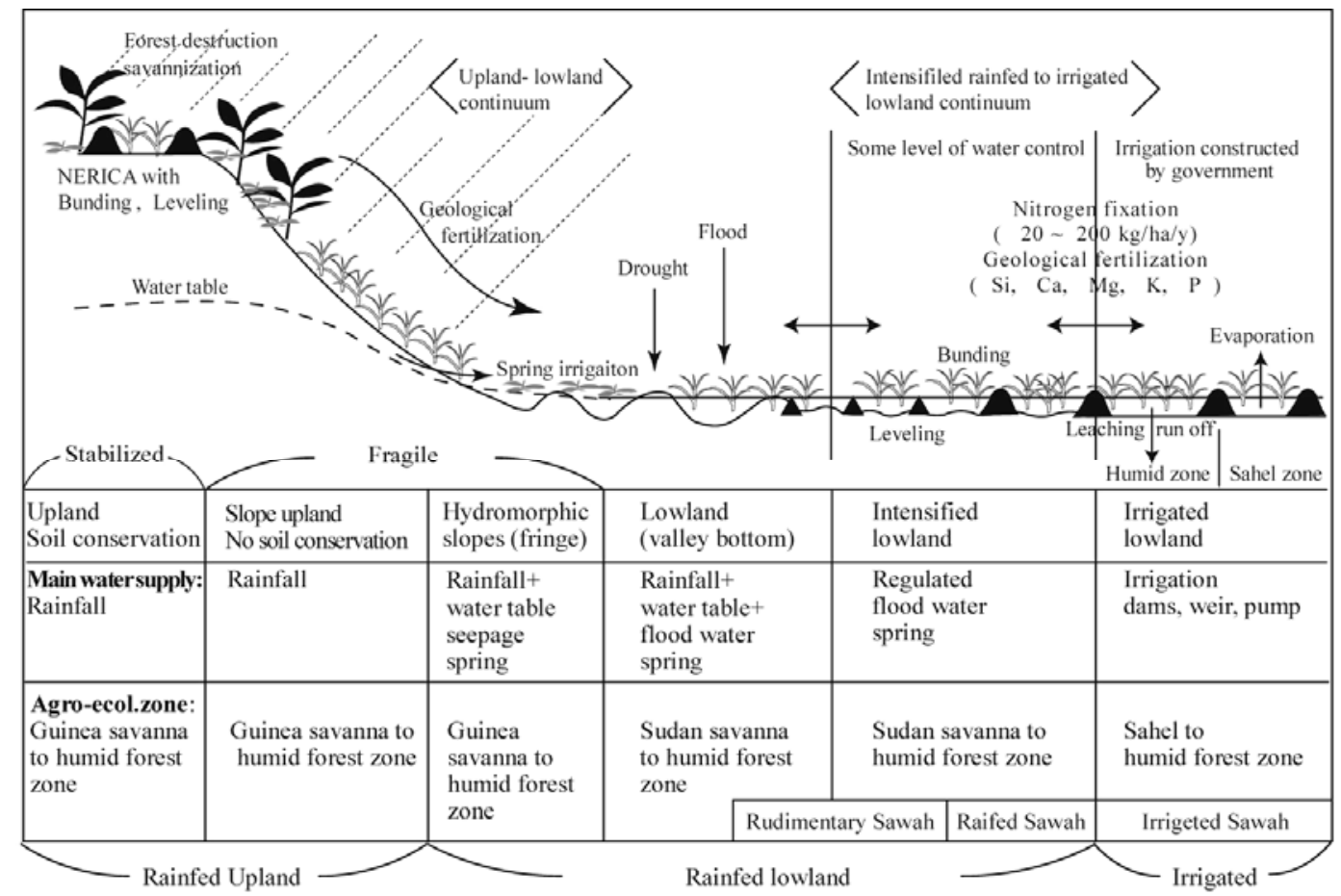

Fig 3: Rice ecologies along a continuum of inland valley watershed and floodplains (Wakatsuki et al. 2003) 
the management broke down and the farmers' were left with no choice but to revert back to their old ways of little or no water control that they had been used to from the upland cultivation. The upland on the other hand was fast becoming competitive and the pressure on the available land was making them loss their fertility status. This was because the demand for increased food production due to increased population and need for infrastructure necessitated by urbanization were forcing the farmers to shorten the fallow periods even as more land are been deforested.

Upland rice cultivation followed the traditional shifting cultivation of slash and burn across rice growing environment. This however did not pose any environmental hazard since there was 10-15 years of fallow at the initial years. However, in recent years fallow period had shortened to 3-5 years or less in some cases making regeneration of the forest practically impossible. This led to progressive expansion of barren land where neither farming nor forest restoration with a long fallow period can be hoped (Wakatsuki et al. 2003). It is estimated that some 2 million ha of land has become barren in Nigeria in the last 20 years due to upland rice cultivation (Hirose and Wakatsuki 2002). Zinc deficiency is now a problem under reduced fallow period of cropping. Singh et al (1997) equally said the soils in the northern part of Nigeria are deficient in organic matter, nitrogen, phosphorus and iron. While in the humid forest zone the upland soils are ferallitic - acidic with $\mathrm{pH}$ of 4.5 , leached, and phosphorus deficient. Iron deficiency is gradually becoming a noticeable problem as well especially with continuous cropping. The average yield of upland rice is around $1.0 \mathrm{t} / \mathrm{ha}$ despite its potential of $2.5 \mathrm{t} / \mathrm{ha}$ for the southern zone and $3 \mathrm{t} / \mathrm{ha}$ in the northern zone, which is largely due to reducing soil fertility (Singh et al; 1997).

Contrary to what is obtained on the farmer's fields, the farming infrastructures had been improved by means of bunding (terracing) and levelling, etc. to prevent soil erosion at farming fields of WARDA, NCRI where these modern varieties are bred. Consequently, a wide yield gaps exist between the actual farming communities and the research stations. However, given the current situation in Nigeria, the conversion of slash and burn shifting cultivation sites to permanent and sustainable upland rice fields is difficult.

\section{Rainfed Lowland}

In Nigeria rainfed lowland currently accounts for 47 per cent of the area cultivated to rice even though its potential could be 65 per cent. Rice cultivation here takes place at sites where the amount of available water exceeds the annual rainfall level due to the topographical condition of lowland. However, rainfed upland and rainfed lowland are located on a toposequence Fig 3. In this paper, rice cultivation at a site where the groundwater level does not reach the ground surface is classified as rainfed upland rice cultivation while rice cultivation on land below that point is classified as rainfed lowland rice cultivation. Rice is cultivated on such land with different levels of water management depending on the experience and skill of the rice farmers. The different features of this land include lowland in inland small catchment areas, lower land just below upland and further lower land, including flood plains. Rainfed lowland can be classified into the following three categories based on the topography and type of development even though it is difficult to draw clear boundary lines between them (Fig 3).

(a) Hydromorphic slope (Fringe) 
In the case of hydromorphic slopes in a groundwater fluctuation area, it is possible to gain access to seepage and spring water in addition to rainwater and groundwater. In such a case, multiple block irrigation is possible. Such multiple block irrigation in the form of small compartment quasi-sawah fields (Rudimentary sawah) is widely observed in inland small lowland areas near Bida in Nigeria using spring water (Ishida et al 2001; Hirose and Wakatsuki 2002). Spring water is also observed in small lowland areas near Ashanti in Ghana and is used for fishponds and sawah fields although most farmers in these areas cultivate rice using the naturally flat ground without creating sawah fields (Wakatsuki et al 1998). To be exact, the land is not entirely flat as undulations of up to one meter, including those caused by anthills, are observed (Fig. 3). Because of this, the common local practice is for rice to be cultivated at sites with an irregular mixture of droughty land, which is constantly dry due to the shortage of water, and flood land where the standing water or deep-water condition is dominant.

At hydromorphic slopes, seepage water is used for irrigation as the water table rises during rain. When there is no rain, the ground water table rapidly drops, making rice cultivation similar to upland rice cultivation. As these slopes are most liable to soil erosion from the topographical point of view, the soil fertility tends to be lower than that of upland let alone lowland. NERICA varieties, which, are supposed to be highly resistant to drought and poor soil, may demonstrate their true value for this type of rice ecology. However, NERICA varieties (WARDA 2002, Takase et. al 2003), which are currently upland rice varieties, appear to suffer from various physiological disorders when cultivated under submerged water. It is, therefore, hoped that a new varieties, which are suitable for cultivation in rainfed lowland areas will be developed.

\section{(b) Inland Valley Bottom}

The size, micro-topography and river flow rate of an inland valley (IV) bottom plains vary depending on the annual rainfall, size of the catchment area and geological as well as topographical conditions. When the catchment area is small (approximately less than 500 ha for a tropical forest belt, less than 2,000 ha for a transitional forest zone, less than 3,000 ha for savannah in Guinea or less than 5,000 ha for savannah in Sudan), it is rare for the water flow of a river to continue for more than half of the year with flooding of inland valley bottom lowland seldom being observed. Normally, the width of an inland valley bottom plain does not exceed several hundred meters and the flood discharge does not exceed several tons per second. When a catchment area is larger than the above case, the flow of river water continues for $6-10$ months with flooding to a certain extent. In inland valley bottom lowland areas, high ground which almost acts as natural levees are formed near a river channel and such topographical differentiation as back swamp and slopes descending from the upland can be observed. The flood discharge may reach $10 \mathrm{t} /$ second in some cases.

In the case of small lowland areas situated in a catchment area of up to the above-mentioned size, the development of infrastructure for water control is possible based on joint work by a village-farmers' group with some assistance provided by an engineer of a public organization. In the history of sawah field development in Japan, primary development in the Yayoi Period, sawah based rice cultivation had started in Japan about 3000 years ago, was made possible by weirs constructed across small rivers (Honma, 1998). This is the simplest way of creating a sawah field system in Nigeria, which has no previous experience of sawah rice cultivation. One difference is that while rocks and stones to build weirs were readily available in Japan and Asia, 
the use of woods, plastic sandbags, concrete and cement blocks or similar will be essential in Nigeria. Given the very gentle gradient of lowland, the creation of levelled sawah fields is relatively simple. However, accurate surveying to ensure water distribution throughout the system is essential. This latter requirement, in fact, makes it difficult for farmers to develop irrigated sawah fields by themselves even in rainfed lowland areas. When farmers have no previous experience of sawah systems, technical assistance at the early stage of development is necessary. Nevertheless, sawah systems can be developed relatively easily with the self-help efforts of farmers in rainfed lowland areas (Wakatsuki et al., 2001). After the participation, every independent successful development of sawah system, it will be also necessary for institutional support for the formation of appropriate farmers' organization and technological support for sustainable water management. West Africa as a whole is estimated to have the potential for the development of some 9 million ha of sawah systems in small lowland areas of inland valley systems (Windmeijer et al., 1993).

There has been little effort so far to localise sawah system development technologies to support the self-help efforts of local engineers, extension workers and farmers' groups in West African. However, as sawah based farming in Nigeria now has a history of more than $20-30$ years and both the qualitative and quantitative levels of farmers, extension workers, agricultural engineers and researchers have much improved. This situation is vividly illustrated by the ongoing development of sawah fields in the Côte d'Ivoire under the Food for Work Program of the WFP recently (Nagumo 2003).

(c) Intensified Rainfed Lowland

As mentioned above, the self-reliant development of sawah fields in small lowland areas by farmers or farmers' groups has been making much progress throughout West Africa and in Nigeria in particular in recent years. Farmers have developed various hand-made small irrigation systems. These are systems using small pump costing some US\$ 500 without the construction of a weir or water canal, using spring water, systems by means of water harvesting where out-flowing water from upland is guided to rainfed sawah fields, systems using a simple weir made of wooden piles, and systems of soil and wooden dykes with irrigation canals over more than several kilometers. Moreover, the manual levelling of fields is often observed along with ridges of various forms and sizes. In short, rice cultivation at lowland sawah fields appears to be spreading all over West Africa with various levels of water control.

\section{Rice Soil Conditions}

Lowland soils are generally more fertile than the upland soils as show in Table 2. Not shown is the fact that all lowlands have better texture especially more clay percentages than the uplands. As explained earlier, they equally posses through proper managing the geological fertilization ability for sustainable long-term usage. Available phosphorus is seen as low but with sawah system available phosphorus levels is released especially in the $0-5 \mathrm{~cm}$ level of the soil. Iron deficiencies, that are fast becoming a problem in upland soils due to continue use, is not a problem with the lowland soils. Balance nutrient level coupled with good cultural practices the iron toxicity observed in some fields are managed. Farmers are known to plant on ridges in combination with tolerant modern varieties to escape the effect of iron toxicity. 
An observable future of the rainfed lowlands is the wide variability of the soil chemical properties, which are due to their relative position on the toposequence, water control system in place and the farming practices. The development of the sawah system will over time homogenise the soil nutrient, increase and build up the clay through the sedimentation of the erosion water coming from the upland.

Table 2: Selected lowland and upland soil chemical properties from fields around Bida

\begin{tabular}{|l|l|l|l|l|l|l|l|}
\hline & $\begin{array}{l}\text { Ejite } \\
\text { lowland }\end{array}$ & $\begin{array}{l}\text { Emitsun } \\
\text { lowland }\end{array}$ & $\begin{array}{l}\text { Emitsun } \\
\text { lowland }\end{array}$ & $\begin{array}{l}\text { Emitsun } \\
\text { upland }\end{array}$ & $\begin{array}{l}\text { Emitsun } \\
\text { upland }\end{array}$ & $\begin{array}{l}\text { ManBuh } \\
\text { upland }\end{array}$ & $\begin{array}{l}\text { ManBuh } \\
\text { upland }\end{array}$ \\
\hline $\mathrm{pH}$ & 4.4 & 5.3 & 5.0 & 5.5 & 6.0 & 5.1 & 4.9 \\
\hline TN $(\mathbf{g} / \mathbf{k g})$ & $\mathbf{0 . 6 9}$ & $\mathbf{0 . 6 4}$ & $\mathbf{0 . 9 7}$ & $\mathbf{0 . 3 0}$ & $\mathbf{0 . 2 6}$ & $\mathbf{0 . 2 0}$ & $\mathbf{0 . 2 0}$ \\
\hline OrgC $(\%)$ & 0.66 & 0.60 & 1.20 & 1.50 & 0.63 & 0.26 & 0.21 \\
\hline $\mathrm{AvP}(\mathrm{ppm})$ & 2.70 & 0.66 & 0.93 & 0.76 & 0.70 & 1.60 & 1.70 \\
\hline $\mathrm{K}(\mathrm{cmol} / \mathrm{kg})$ & 0.06 & 0.16 & 0.21 & 0.31 & 0.20 & 0.04 & 0.04 \\
\hline $\mathrm{Ca}(\mathrm{cmol} / \mathrm{kg})$ & 1.40 & 1.23 & 1.58 & 1.47 & 1.37 & 0.50 & 0.40 \\
\hline $\mathrm{Mg}(\mathrm{cmol} / \mathrm{kg})$ & 0.2 & 0.56 & 0.55 & 0.45 & 0.50 & 0.1 & 0.1 \\
\hline Fe (ppm) & $\mathbf{3 8 6 . 8}$ & $\mathbf{1 5 1 . 9}$ & $\mathbf{1 6 7 . 6}$ & $\mathbf{1 8 . 1}$ & $\mathbf{8 . 9}$ & $\mathbf{2 0 5 . 3}$ & $\mathbf{1 5 9 . 2}$ \\
\hline $\mathrm{Zn}(\mathrm{ppm})$ & 0.9 & 0.2 & 0.04 & 0.4 & 0.6 & 0.6 & 0.6 \\
\hline $\mathrm{Mn}(\mathrm{ppm})$ & 33.8 & 20.2 & 8.1 & 25.9 & 23.8 & 1.9 & 2.9 \\
\hline
\end{tabular}

\section{Grain yield under different water management systems.}

During 1986 to 1992 IITA scientists conducted various on-farm trials on farmer's fields either as farmer managed or researcher managed trials. However since 2001, when the sawah systems as a technology was introduced to the Bida rice farmers of Niger State, the farmers were left to solely manage their field; the only input supplied was the power tiller used for their land preparation. However, a monitoring of the various activities by the farmers were done and the farmers were grouped into two categories namely 1) farmers with puddled and bunded fields (sawah plot) and 2) farmers with traditional tillage system (non-sawah plots). All farmers used about $30 \mathrm{~kg} \mathrm{~N} / \mathrm{ha}$ of fertilizer and their varieties were improved. All farmers' fields with sawah technology out yielded the non-sawah plots (Fig 4). The yield range for the sawah plots were from 3.5 to $5.5 \mathrm{t} /$ ha whereas the non-sawah plot had a range of between 1.2 to $1.9 \mathrm{t} / \mathrm{ha}$. On the sawah plots, higher yields were equally observed with plots that had Azolla on their field. The sawah system i.e. the puddling, levelling and bunding, enhanced the nitrogen fixation ability of Azolla.

Labour is a major constraint in lowland rice cultivation especially in the inland valley swamps. It is observed that if the power tiller (a hand driven two-stroke engine machine) (Fig 6) is introduced and adopted by rice farmers, labour constraints would had be solved and the added benefit is that the water management would be enhanced, and adoption of sawah technology could be possible and made easy. 


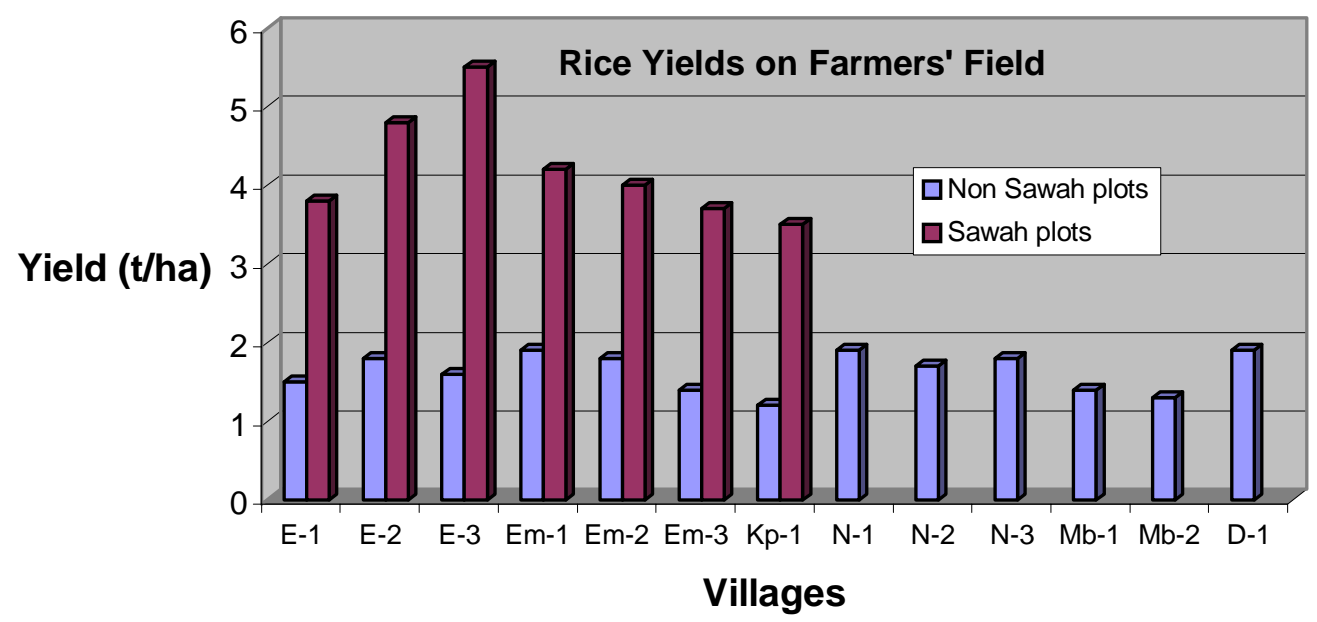

Figure 4: Yield Comparison between Sawah and non-Sawah plots on Farmers' Field

Figure 5 is the result from a one-ha production field on farmers field. The field is divided into 16 plots with plot sizes ranging from 490 to $711 \mathrm{~m}^{2}$. In 2002 the first year of production 11 plots were cultivated with WITA 4 and $80 \mathrm{~kg} \mathrm{~N}$ per ha was used, the plots were puddle. The yield range of 2.2 to $6.8 \mathrm{t} / \mathrm{ha}$ was gotten but a physical harvest was more than 2 tons was collected from 0.6 ha. The variability seen on the plots were as a result of poor water management in some plots.

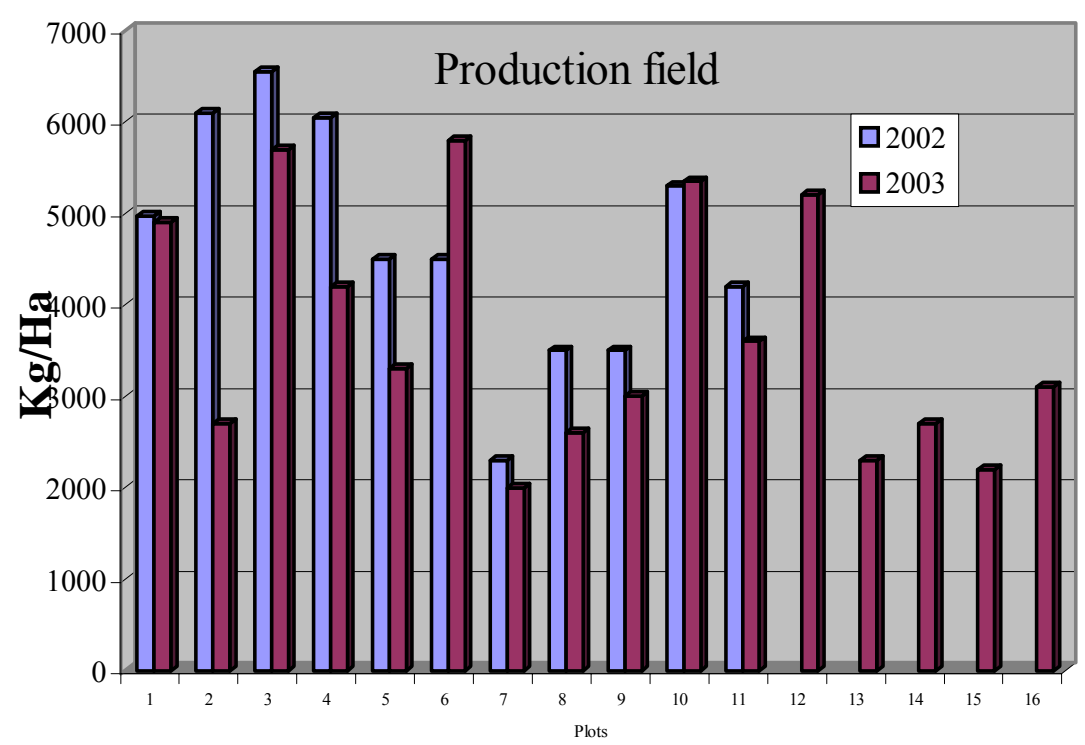

Figure 5: Grain yield for two years in One-hectare field on Farmer's Field 
In 2003 all the one-ha plot was planted to WITA 4 with $75 \mathrm{~kg} \mathrm{~N} /$ ha fertilizer was used. An amount of levelling and puddling was done in some plots. As noticed in plot 2 (Fig 5) a large amount of topsoil was moved so as to levelled the plot for water distribution. This resulted in the low yield observed. As the plots get more homogenous in soil fertility, so will the grain yield improve and increase. Over 3 tons was harvested physically from the field.

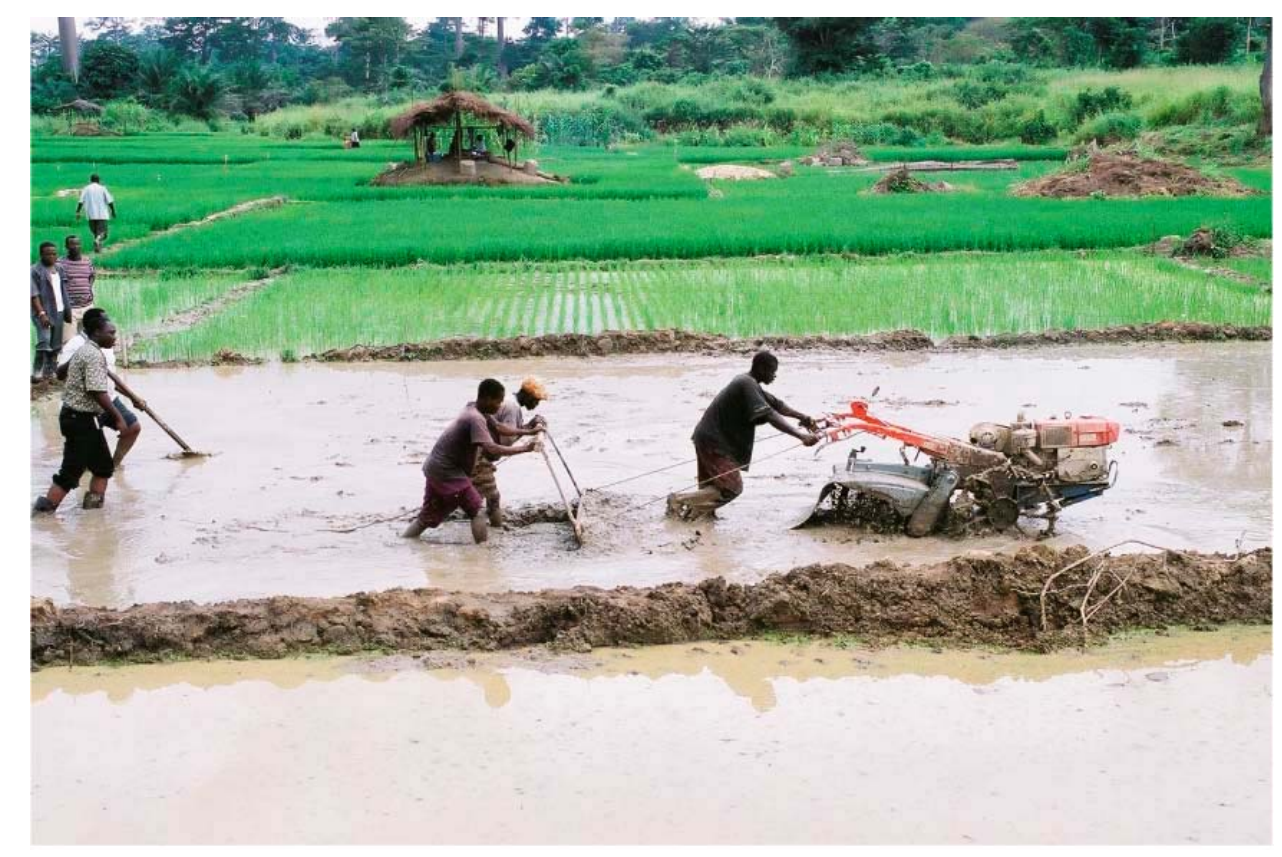

Figure 6: Levelling and puddling (Sawah) on farmer's field at Kumasi, Ghana.

Figure 6 is a demonstration of the use of the power tiller on a farmer's field. The power tiller is a simple two-stroke engine, hand driven machine with 13-horse power. It is an appropriate technology for the inland valleys (lowland cultivation). It is equally a multi functional and multi-purpose machine and it is affordable. Having bunded the field into manageable plots, the soil can be leveled, puddled and water management is better enhanced. This will enhance the build up of the silt and clay in the water on the plots. The weeds are suppressed given that the rice has a better headstart and reduced weeding frequency had been document in many literatures. Also fertilizer use efficiency is greatly improved and the high yielding varieties would be able to demonstrate their inherent potential of high yields of between 4 to $6 \mathrm{t} / \mathrm{ha}$ ).

\section{Eco-technology approach to low-cost sustainable Sawah development in Inland Valleys}

It is now very difficult to build new irrigation project through traditional way of grants and loans because of the high cost of irrigation and its apparent low net return. As shown in Table 3, a large-scale irrigation project is very costly. Although the total sales of produces are between US\$1000-1500/ha, the running cost including maintenance of the systems, machinery for operation and agrochemicals for rice cultivation are very high. Due to the high construction cost, the economic return has been negligible or rather negative for a long period of time (20-30 years). Owing to various problems in large scheme, small irrigation schemes are considered more suitable to develop at present. However, with the present small irrigation schemes, the 
construction cost is comparable to large schemes as far as their development depends mainly on engineering work by experts. Therefore the project ownership still belongs to the government (engineers) rather than the farmers. The production level of rice farmers could not compensate for the high construction cost. As described below, the eco-technology approach to sustainable sawah development proposed by the joint study between JICA/ Ghana will be a promising new method (Wakatsuki et al 2001; Hirose and Wakatsuki 2002).

Table 3. Comparison of past large scale, present small scale, traditional system and ecotechnology based sustainable irrigation development in Ghana.

\begin{tabular}{|c|c|c|c|c|}
\hline & $\begin{array}{l}\text { Large Scale } \\
\text { Development }\end{array}$ & $\begin{array}{l}\text { Medium Scale } \\
\text { Development }\end{array}$ & $\begin{array}{l}\text { Ecotechnology } \\
\text { Approach to Sawah } \\
\text { Development }\end{array}$ & $\begin{array}{l}\text { Traditional } \\
\text { System }\end{array}$ \\
\hline $\begin{array}{l}\text { Development cost per } \\
\text { hectare }\end{array}$ & $\begin{array}{c}20,000-30,000 \\
\text { US } \$ / \text { ha }\end{array}$ & $\begin{array}{c}20,000-30,000 \\
\text { US\$/ha }\end{array}$ & $\begin{array}{l}\text { 3,000-4,000 } \\
\text { US\$/ha }\end{array}$ & $\begin{array}{l}20-30 \\
\text { US\$/ha }\end{array}$ \\
\hline $\begin{array}{l}\text { Economic returns of } \\
\text { rice and vegetable etc. }\end{array}$ & $\begin{array}{c}1,000-2,000 \\
\text { US } \$ / \text { ha }\end{array}$ & $\begin{array}{c}1,000-2,000 \\
\text { US } \$ / \text { ha }\end{array}$ & $\begin{array}{c}\text { 1,000-2,000 } \\
\text { US\$/ha }\end{array}$ & $\begin{array}{l}100-300 \\
\text { US\$/ha }\end{array}$ \\
\hline $\begin{array}{l}\text { Possible income } \\
\text { (Economic Returns) }\end{array}$ & Negative & Negative & 1,000 US\$/ha & $100-200$ US\$/ha \\
\hline $\begin{array}{l}\text { Maintenance cost for } \\
\text { the system }\end{array}$ & High & Medium & Low & Zero \\
\hline $\begin{array}{l}\text { Running cost including } \\
\text { machinery }\end{array}$ & $\begin{array}{l}\text { Medium to High } \\
\text { (300-600 US\$/ha) }\end{array}$ & $\begin{array}{l}\text { Medium to High } \\
\text { (300-600 US\$/ha) }\end{array}$ & $\begin{array}{c}\text { Medium } \\
\text { (200-300 US\$/ha) }\end{array}$ & $\begin{array}{c}\text { Low } \\
(10-20 \text { US } \$ / h a)\end{array}$ \\
\hline Farmers participating & Low & Medium to High & High & High \\
\hline Type of farmer & New migrants & $\begin{array}{l}\text { Old/ New migrants } \\
\text { and indigenous }\end{array}$ & $\begin{array}{l}\text { Old migrants and } \\
\text { indigenous }\end{array}$ & $\begin{array}{l}\text { Old migrants and } \\
\text { indigenous }\end{array}$ \\
\hline Project ownership & Government & Government & Farmer & Farmer \\
\hline Type of technology & $\begin{array}{l}\text { High input rice } \\
\text { based agronomy } \\
\text { including } \\
\text { machinery }\end{array}$ & $\begin{array}{l}\text { High input rice } \\
\text { based agronomy } \\
\text { including } \\
\text { machinery }\end{array}$ & $\begin{array}{l}\text { Sawah Ecotechnology } \\
\text { and medium input rice } \\
\text { based agronomy } \\
\text { including small } \\
\text { machinery }\end{array}$ & Low input \\
\hline Adoption of technology & Long, difficult & $\begin{array}{l}\text { Short, relatively } \\
\text { easy }\end{array}$ & $\begin{array}{l}\text { Medium to short, needs } \\
\text { intensive demonstration } \\
\text { and On the Job } \\
\text { Training (OJT) } \\
\text { programme } \\
\end{array}$ & $\begin{array}{l}\text { Little technology } \\
\text { transfer }\end{array}$ \\
\hline $\begin{array}{l}\text { Sustainable } \\
\text { development }\end{array}$ & Low & Low to Medium & High & Medium \\
\hline Environmental effect & High & Medium & Low & Medium \\
\hline
\end{tabular}

Restoration of degraded inland valley watersheds in West Africa: A case study of ecological engineering project 
The term, Ecological Engineering Technology (Eco-Technology), is defined here as an ecology-based sustainable farming technology viable to local socio-cultural systems to increase farming productivity and to improve the environment. The ecotechnology developed should be able to be used by local farmers to control water and to conserve water and soil. Levelling, bunding, and construction of canal and head dyke are the example of such eco-technologies, which can be practiced as an extension of agronomic practices using locally available tools and materials. Forestry technology, such as nursery preparation and management, contour bunding planting of the useful (fruit) trees, regeneration of the water and soil conservation forest, and to establish carbon sequestration against global warming are the examples of the ecotechnology which this project are going to develop. The eco-technology will be the key technology to attract local farmers' active participation for the improvement of basic agricultural infrastructure, such as irrigation and soil conservation measure. The eco-technology will be able to integrate partly between agronomy and agricultural engineering as well as ecological sciences and various engineering.

The focus of research activities is to develop suitable Ecological Engineering Technologies (Eco-Technologies) for integrated watershed/rural development through increasing sustainable productivity and at the same time through improving the total water cycling in a given watershed. Eco-technologies should be adaptive to indigenous farming systems and rural village society. Various area of benchmark watersheds, from 100 to $10000 \mathrm{ha}$, which is located 10-20 km southwest from Bida, has been selected for basic agroecological survey. Among and surrounding watersheds, various sized watersheds including Ejite, Emistundada, Gadza, Nassarafu and Manbuhari villages were selected for detailed survey and intensive field testing for participatory low cost sustainable sawah development through the Japanese government support.

However for a wide adoption to be possible the government need to make a better enabling environment. Brief lists of what the government would need to look into are below:

* In-consistent policy on agriculture especially as it relates to rice. For example banning and un-banning of rice importation

* Poor policy implementation on fertilizer distribution

* In-consistency on fertilizer subsidy and pricing

* Poor rural infrastructure especially access and rural roads

* Lack off or difficulty in getting access to farm credit for resource poor farmers

* Introduction of appropriate technology for example power tillers for rice farmers not conventional tractors.

In conclusion rice productivity per unit area (productivity/ha) in Nigeria had been low due to the fact that the soil and water management practices had been poor (Fashola et al 2002; Fashola and Wakatsuki 2003).

Therefore, with improved access to affordable fertilizer when needed, in combination with the available high yielding varieties (Singh and Fashola 1994) couple with the adoption / use of the Sawah system technology for rainfed lowland rice, Nigerian Green Revolution will be achieved and not only are we going to be self sufficient but we shall become a net exporter of paddy rice (Fashola and Wakatsuki 2003). 


\section{Reference:}

FAOSTAT 2004: FAOSTAT Database, http://apps.fao.org

Fashola, O. G. O. Olaniyan, J. Aliyu and T. Wakatsuki. 2002: Comparative evaluation of farmers' paddy field system and the SAWAH system for better and sustainable rice farming in inland valley swamps of Nigeria. In African Crop Science Conference proceedings Vol. 5 pp 615-619

Fashola O. O. and Wakatsuki T. 2003: Problems and Prospects for the Dissemination of Rice Production Technology in West and Central Africa: Focus on the Farming Systems of Moist Savanna Agroecological Zone. Invited paper presented at JICA / AICAD Conference on Agriculture, Food and Water in Africa - Policy and Practice' Sponsored by JICA 11-14 Feb Juja, Kenya.

Hirose S. and Wakatsuki T. 2002: Restoration of inland Valley Ecosystems in West African Savannah, 600 pp., Norin Tokei Kyokai, Tokyo

Honma T. 1998: "Mechanism of Nation Building in Japan: Relationship Between Sawah (Paddy) Field Development and Population Increase" Sankai-do, Tokyo

Hsieh Sung-Ching 2001: Agricultural Reform in Africa - With Special Focus on Taiwan-Assisted Rice Production in Africa, Past, Present and Future Perspectives, Tropics, 11 (1), 33-58

Ishida F., Tian, G and Wakatsuki T. 2001: indigenous knowledge and Soil Management. In G. Tian, F. Ishida and D. Keatinge ed., Sustaining Soil fertility in West Africa p. 91-109, American Society of Agronomy and Soil Science Society of America, Special Publication No. 58, Madison, Wisconsin, USA

Kyuma, K. 1984: Distribution and Characteristics of lowland Soil in the Tropics, Particularly in Southeast Asia. In A Tanaka, ed., Acid Soils and Their Agricultural Utilization - Special Reference to Present and Future Use in the Tropics, p. 102-142, Hakuyusha Publishers, Tokyo

Kyuma K. 2003: Paddy Soil Science, 305 pp., Kyoto University Press

Nagumo F. 2003: Self-support development of Sawah systems at Cote d'Ivore, West Africa, J. Association of International Cooperation of Agriculture and Forestry, Vol. $25(4 / 5), 42-50$

Osiname O. A. 2002: Review of Current Status, Policy and Prospects of Rice Production in Nigeria

Singh B. N., S. Fagade, M. N. Ukwungwu C. Williams S.S. Jagtap O. Oladimeji A. Efisue and O. Okhidievbie. 1997:Rice Growing Environments and Biophysical Constraints in Different Agroecological Zones of Nigeria. Met. J.2(1), pp 35-44

Singh, B. N. and O. O. Fashola 1994: Sustainable wetlands rice production in Northern Nigeria. In eds. A Kolawole, I. Scoores, M. D. Awogbade and J. P. Voh, Strategies for The Sustainable Use of Fadama Lands in Northern Nigeria. FACU, Abuja.

Takase K, Emoto S, and T. Wakatsuki 2003: Study of the methodology for rural 
development of Africa. Special Volume, Studies on the technical cooperation for rice cultivation in West Africa, JICA, Japan International Cooperation Agency, Tokyo

Toon Defoer, Marco C, S Woperies, Monty P J, F Lancon and O Erenstein 2002: "Challenges, Innovation and Change: Towards Rice-Based Food Security in Sub-Saharan Africa", article presented at the $20^{\text {th }}$ Session of the International Rice Commission, Bangkok, 23-25 July

Wakatsuki T. 2002: Possible Self-support development of small scale sawah systems in Inland Valley Watershed at West Africa, Japanese J. Agricultural Engineering, 70 (11), 999-1004

Wakatsuki T, Shinmura Y, Otto E, and Olaniran G. 1998: African based sawah system for the integrated watershed management of small inland valley in West Africa. Water Reports 17, Institutional and technical opinion in the development and management of small-scale irrigation, p. 56-79, FAO, Rome.

Wakatsuki T, Otto E, Andah W E I, Cobbina J, Buri M M, and Kubota D (eds.) 2001: Integrated Watershed Management of Inland Valley in Ghana and West Africa: Ecotechnology Approach, Final Report on JICA/CRI joint study project, 337 pp., CRI, Kumashi, Ghana and JICA, Tokyo

Wakatsuki, T., Buri, M.M. and Fashola, O.O.: 2003 Restoration of Degraded Inland Valley Watersheds in West Africa by Sustainable Sawah Development a paper presented at the International Soil Conference, Accra, Ghana.

WARDA 1988: Strategic plan 1990-2000

WARDA 1997: Looking back into the future. Presentation by Kanayo F. Nwanze, Director General of West Africa Rice Development Association (WARDA), at International Centers Week, 27-31 October 1997, Washington D.C. USA

WARDA 2002: The African Rice Initiative (ARI): NERICA Consortium for Food Security in Sub-Sahara African, 40pp.

Windmeijer P.N. and Andriesse W. eds 1993: Inland Valley in West Africa: An AgroEcological Characterisation of Rice-Growing Environment, ILRI Publication 52, Wageningen, the Netherlands. 